\title{
POLARIZATION DEPENDENCE OF HOLOGRAPHIC RECORDING IN GLASSY AZOCOMPOUNDS
}

\author{
A. Ozols, V. Kokars, P. Augustovs, I. Uiska, K. Traskovskis, G. Mezinskis, A. Pludons, \\ and D. Saharov \\ Faculty of Materials Science and Applied Chemistry, Riga Technical University, Azenes 14/24, LV-1048 Riga, Latvia \\ E-mail: aozols@latnet.lv
}

Received 25 August 2009; revised 6 March 2010; accepted 19 March 2010

\begin{abstract}
Polarization dependence of holographic grating recording in glassy molecular azobenzene films $\mathbf{8 a}, \mathbf{1 1}$, and $\mathbf{1 6}$ has been experimentally studied at 633 and $532 \mathrm{~nm}$ with s-s, p-p, CE-1 and CE-2 circular-elliptic (differing by light electric field rotation directions) recording beam polarizations. Samples 8a and 11 with the simplest chemical structure were the most efficient at $633 \mathrm{~nm}$, and sample $8 \mathbf{a}$ was the most efficient at $532 \mathrm{~nm}$. Self-diffraction efficiency (SDE) up to $45 \%$ was achieved in 8a with p-p polarized recording beams at $633 \mathrm{~nm}$. Linear p-p polarizations were the most efficient at $633 \mathrm{~nm}$ whereas CE-1 polarizations were the best at $532 \mathrm{~nm}$. It was found that the light polarization changes in the process of diffraction depend on chemical composition, wavelength, and exposure time. Vector gratings with SDE up to $25 \%$ were recorded in 8a rotating a linear polarization by $90^{\circ}$. Mainly erasure of gratings took place with one beam. Coherent self-enhancement of gratings was observed only for $\mathrm{s}-\mathrm{p}$ and both CE polarizations in $8 \mathbf{a}$ at $532 \mathrm{~nm}$ and for s-p polarizations at $633 \mathrm{~nm}$. Atomic force microscopy measurements also were made. The evidence is found for trans-cis photoisomerization holographic recording mechanism at both 532 and $633 \mathrm{~nm}$. Studied films can be applied for production of polarization holographic optical elements and for permanent optical information recording.
\end{abstract}

Keywords: molecular glassy azobenzene films, holographic gratings, light polarization, diffraction anisotropy

PACS: 72.80.Le, 78.47.jj, 78.20.-e

\section{Introduction}

There is a growing interest to organic materials for the applications in holography and nonlinear optics because organic materials enable much easier tailoring of their properties than inorganic ones since there are about 15 millions of organic compounds compared to only about one million of inorganic compounds [14]. Azocompounds are among the most efficient holographic recording materials $[1,4,5]$. Usually, UV, blue, or green light is used for recording $[1,4,5]$ since absorption at longer wavelengths is too low. However, the extension of the spectral range to the red region is of theoretical and practical interest. As is known from laser theory, the lasing processes dictate that energy requirements scale as $\sim \lambda^{-4}$ where $\lambda$ is the wavelength of the laser radiation. Therefore, red lasers are cheaper than blue-green and UV lasers. Besides, with a red light a higher quality of volume holographic optical elements can be achieved because recording materials mainly absorb in the blue or green spectral region, and a more homogeneous exposure through the volume can be obtained with a red light.

The mechanisms of the photoinduced processes in the red spectral range are still unclear $[2,4,6]$. Recently we have found that quite efficient holographic recording is possible by a red He-Ne laser light in stilbene azobenzene derivatives including surface relief grating (SRG) recording with $226 \mathrm{~nm}$ thickness change [7,8]. The conclusion was made that, most probably, the azochromophore photodegradation mechanism was responsible for SRG recording but other mechanisms including trans-cis photoisomerization could contribute as well. In this paper, we have continued experimental studies of the best stilbene azobenzene derivative 8a (the precise chemical designation of this and other chemical structures will be given below) widening the recording light spectral and polarization range. Besides, new glassy molecular compounds $\mathbf{1 1}$ and $\mathbf{1 6}$ have been studied as well. Holographic gratings have been recorded with different polarizations and their efficiency is compared. Polarization changes were monitored in the process of diffraction. Vector holograms rotating the read- 


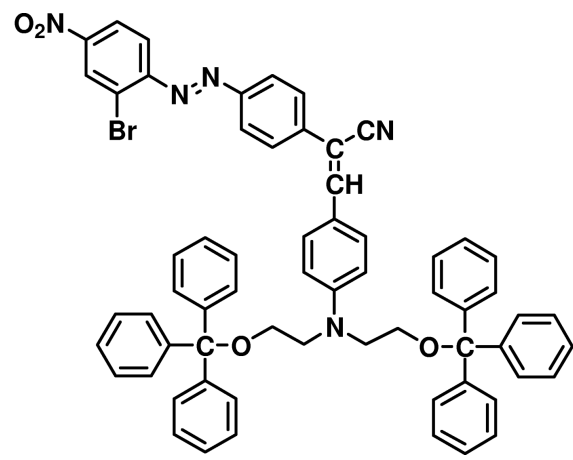

Fig. 1. Chemical structure of the sample $\mathbf{8 a}$.

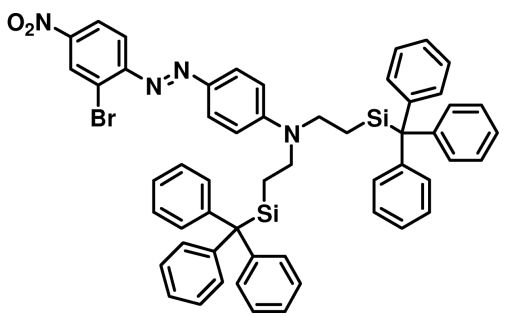

Fig. 2. Chemical structure of the sample $\mathbf{1 1}$.

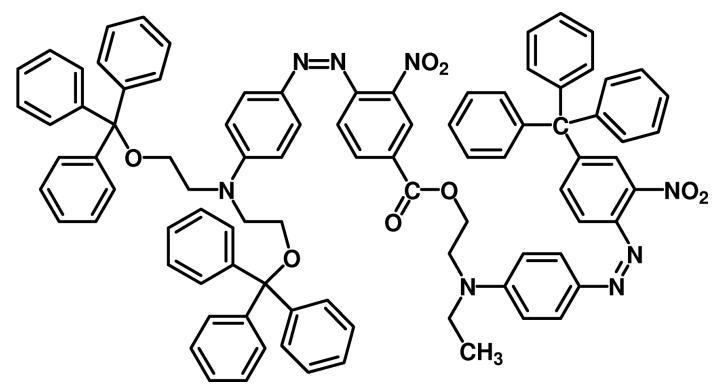

Fig. 3. Chemical structure of the sample 16.

out beam polarization were recorded. The possibility of coherent self-enhancement of gratings during readout by one of the recording beams was studied. In some cases the recorded gratings were measured by AFM and SRG were found. Among other results, these studies have given the evidence that red light induced trans-cis photoisomerization is possible.

\section{Samples and experimental procedure}

Studied azobenzene molecular glasses were synthesized and characterized in our faculty [9]. In this paper the three best of them are described, namely, 8a or 3-(4-(bis(2-(trityloxy)ethyl)amino)phenyl)-2-(4(2-bromo-4-nitrophenyl) diazenyl)phenyl)acrylonitrile, 11 or 4-((2-bromo-4-nitrophenyl)diazenyl)-N,N-bis(2(triphenylsilyloxy)ethyl)benzenamine, and $\mathbf{1 6}$ or 2(ethyl (4-((2-nitro-4-triphenyl)diazenyl) phenyl) amino) ethyl - 4 - (( 4 - bis ( 2 - ( trityloxy) ethyl) amino) phenyl) diazenyl)-3-nitrobenzoate. Their chemical structure is shown in Figs. 1-3. Thin films of these glasses were spin-coated on glass substrates. Their absorption spectra and thickness were measured. The absorption spectra were measured by Perkin Elmer Lambda 35 Spectrometer. The thickness of the films was measured by mechanical contact method using "Kafer Messuhrenfabrik GmbH \& Co. KG" device having precision of about $0.7 \mu \mathrm{m}$. It was found that the long wavelength maxima $\left(\lambda_{\max }\right)$ of the samples corresponding to their trans forms were situated at 510, 507, and $469 \mathrm{~nm}$, respectively. The film thicknesses were 1.6, 2, and $3 \mu \mathrm{m}$. The size of the samples was about $7 \times 7 \mathrm{~cm}^{2}$. We took one sample of each glass.

Holographic gratings with the period of $2 \mu \mathrm{m}$ were recorded and read out either by KLASTECH DENICAFC 532-300 diode pumped solid state laser (recording and readout wavelengths $\lambda_{1}=\lambda_{2}=532 \mathrm{~nm}$ ) or by Melles Griot 25LH928-230 He-Ne gas laser $\left(\lambda_{1}=\right.$ $\lambda_{2}=632.8 \approx 633 \mathrm{~nm}$ ) with two equally strong unfocused beams. The lasers operated in $\mathrm{CW}$ mode. The $1 / \mathrm{e}^{2}$ beam diameters of these lasers were 1.80 and $1.47 \mathrm{~mm}$, respectively. The recording light intensity $(I)$ was $1.2-1.5 \mathrm{~W} / \mathrm{cm}^{2}$. Thus holographic gratings were recorded at the long wavelength side of the trans form absorption peak. Linear s-s, p-p, s-p, and circularelliptic (due to different $\lambda / 4$ plates) CE-1 and CE-2 recording beam light polarizations were used (Figs. 48). The circular beam was either with left or right rotation direction, the elliptic polarization was with the ratio of axes 1:2. Our experiments (taking into account the recording efficiency) indicate that, most probably, CE-1 polarizations had opposite rotation directions but CE-2 had the same rotation directions. First-order selfdiffraction efficiency SDE was continuously measured as the function of exposure time $(t)$ by OPHIR Nova II or Laserstar power meter and stored in the PC memory. SDE is a ratio of a first-order diffracted beam power to the power of the more distant recording beam without the interruption of recording beams. The mathematical relation between SDE and DE is described in [10]. In our experiments we have estimated that $\mathrm{SDE} \approx(0.5-1.6) \mathrm{DE}$. The final diffraction efficiency, $\mathrm{DE}_{\mathrm{f}}$, was also measured. The holographic set-up was mounted on STANDA holographic table with the vibration isolation system. From these measurements the specific recording energies $W_{\max }=I t_{\max } / \mathrm{SDE}_{\max }$ and $W_{\mathrm{f}}=I t_{\mathrm{f}} / \mathrm{DE}_{\mathrm{f}}\left[\mathrm{J} /\left(\mathrm{cm}^{2} \%\right)\right]$ were found. In order to characterize the recording efficiency by one parameter we introduced also the recording efficiency factors $\mathrm{REF}_{\max }=\mathrm{SDE}_{\max } / W_{\max }$ and $\mathrm{REF}_{\mathrm{f}}=\mathrm{DE}_{\mathrm{f}} / W_{\mathrm{f}}$ 


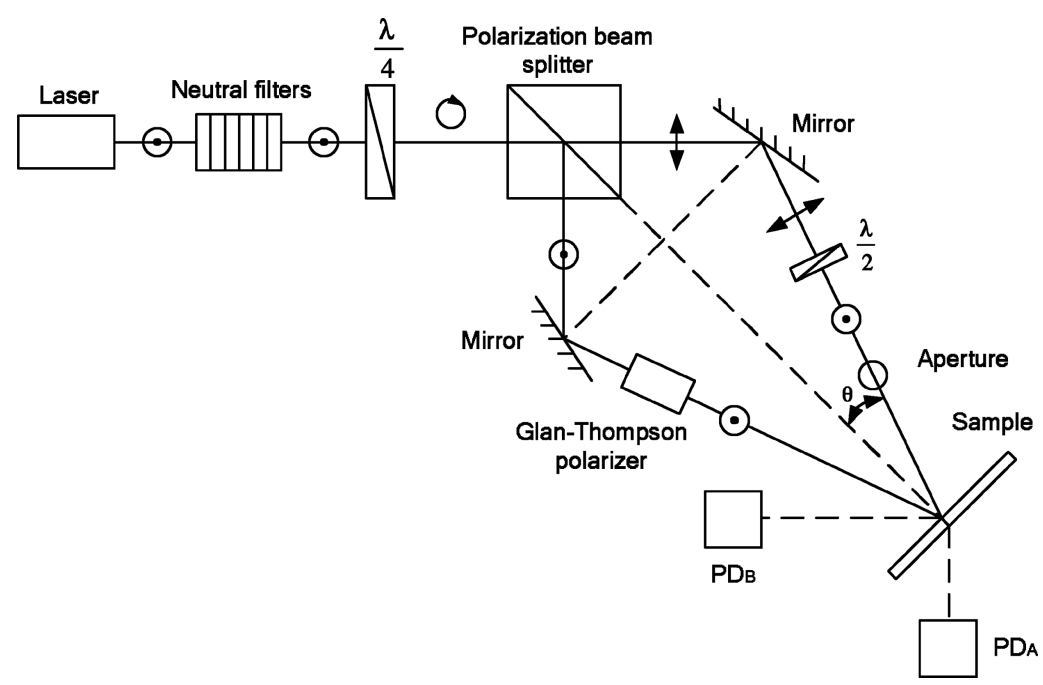

Fig. 4. Holographic recording set-up with s-s polarizations of recording beams.

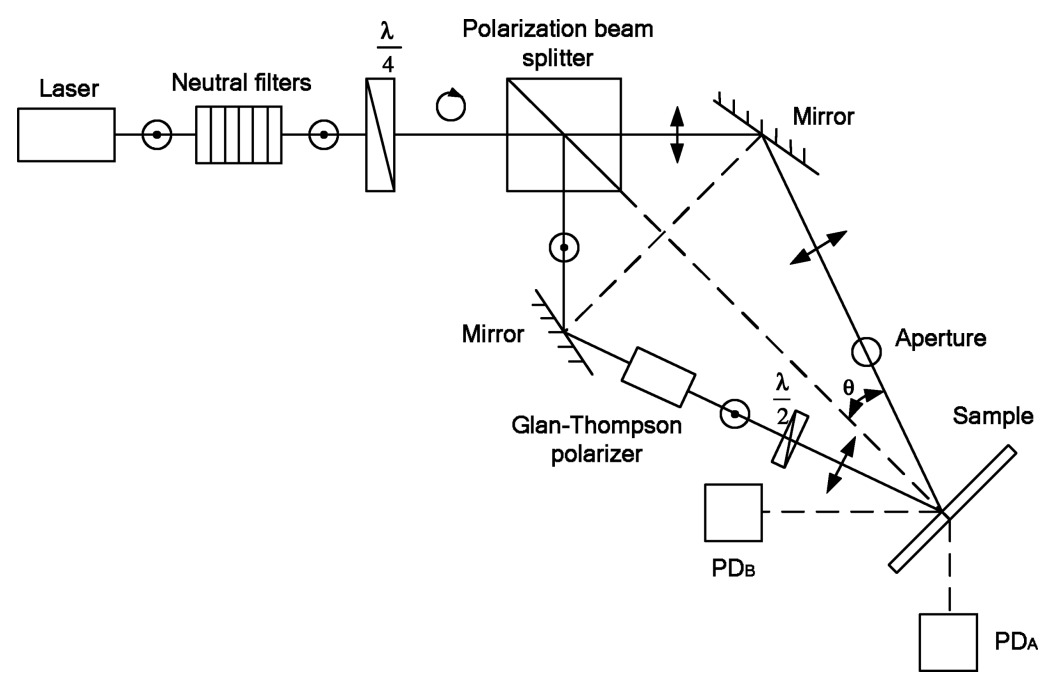

Fig. 5. Holographic recording set-up with $\mathrm{p}-\mathrm{p}$ polarizations of recording beams.

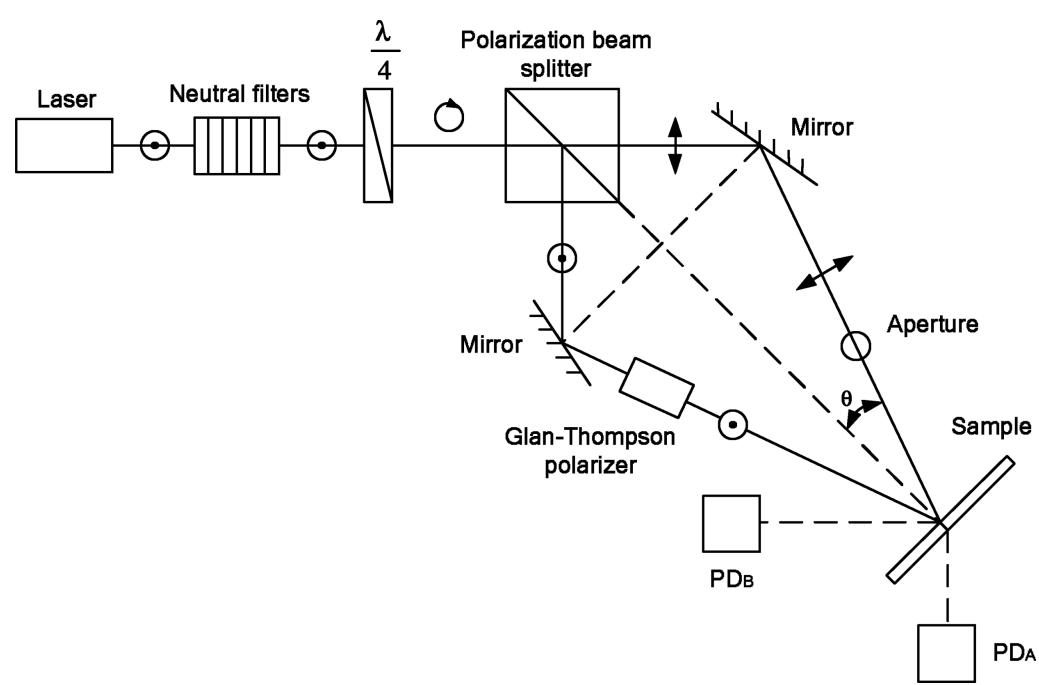

Fig. 6. Holographic recording set-up with s-p polarizations of recording beams. 


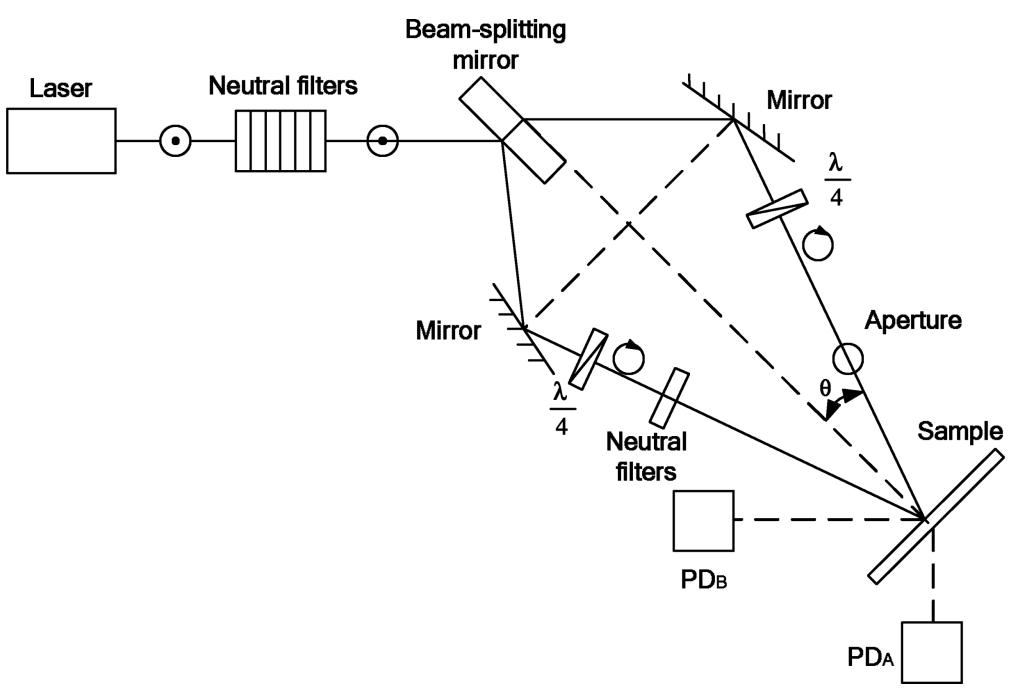

Fig. 7. Holographic recording set-up with CE-1 polarizations of recording beams.

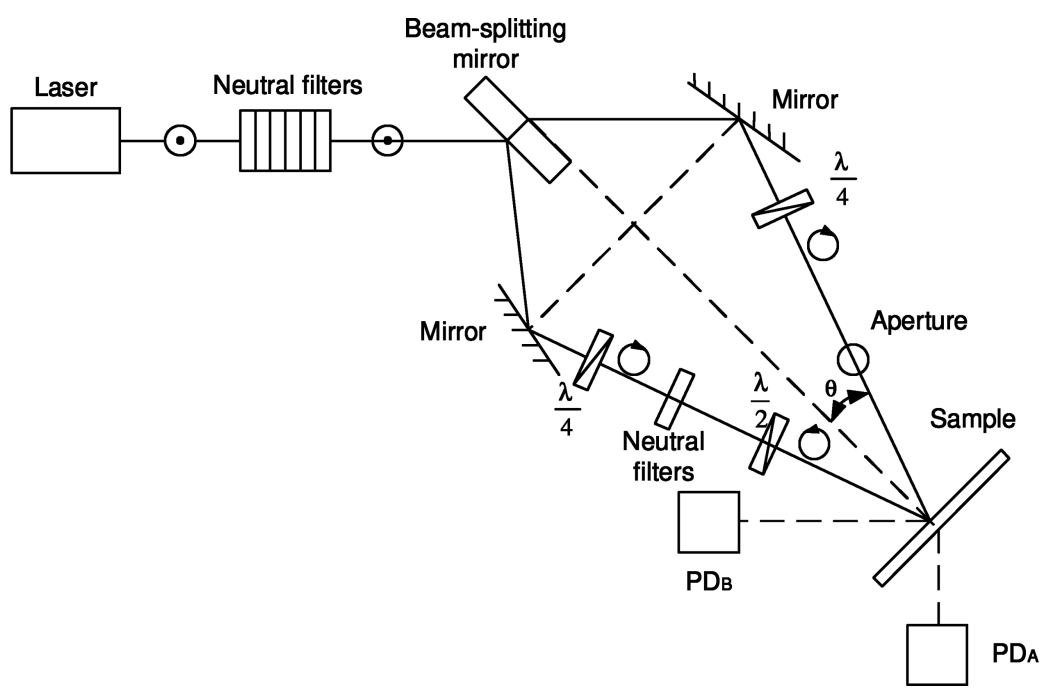

Fig. 8. Holographic recording set-up with CE-2 polarizations of recording beams.

$\left[(\mathrm{cm} \%)^{2} / \mathrm{J}\right]$. We estimate that accuracy of determined SDE, DE, and $W$ values are in the 5-10\% range.

Polarization of diffracted beams in the course and after the s-p recording with orthogonally polarized beams was studied in order to evaluate the possibility of the recording of vector holograms. Besides, the possibility of coherent holographic grating self-enhancement by one of the recording beams [2] was studied as well for all recording beam polarizations.

Apart from holographic measurements atomic force microscope (AFM, type SPM II VEECO) studies of some recorded gratings were made, too. All the experiments were carried out at room temperature.

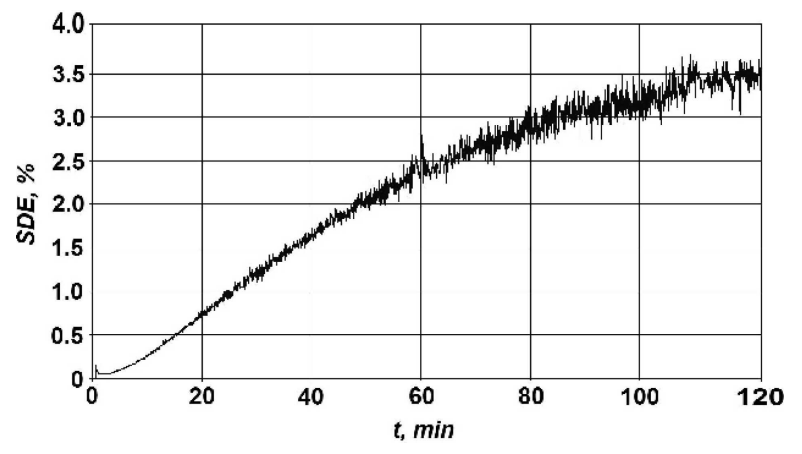

Fig. 9. SDE exposure time dependence for the sample $\mathbf{8 a}$ in the case of s-s recording beam polarizations at $633 \mathrm{~nm}$.

\section{Results and discussion}

The results of holographic measurements are presented in Figs. 9-18 and Tables 1-4. No measurements 
Table 1. Holographic parameters of the sample 8a at $633 \mathrm{~nm}$.

\begin{tabular}{ccccccc}
\hline Polarization & $\mathrm{SDE}_{\max }, \%$ & $W_{\max }, \mathrm{kJ} /\left(\mathrm{cm}^{2} \%\right)$ & $\mathrm{REF}_{\max },(\mathrm{cm} \%)^{2} / \mathrm{kJ}$ & $\mathrm{DE}_{\mathrm{f}}, \%$ & $W_{\mathrm{f}}, \mathrm{kJ} /\left(\mathrm{cm}^{2} \%\right)$ & $\mathrm{REF}_{\mathrm{f}},(\mathrm{cm} \%)^{2} / \mathrm{kJ}$ \\
\hline $\mathrm{s}-\mathrm{s}$ & 3.50 & 3.0 & 1.2 & 4.0 & 2.6 & 1.5 \\
$\mathrm{p}-\mathrm{p}$ & 45.0 & 0.23 & 196 & 12.4 & 0.84 & 15 \\
$\mathrm{~s}-\mathrm{p}$ & 25.0 & 0.43 & 59 & 11.1 & 0.96 & 12 \\
$\mathrm{CE}-1$ & 21.0 & 0.27 & 79 & 4.2 & 1.70 & 2.5 \\
$\mathrm{CE}-2$ & 16.0 & 0.60 & 27 & 10.0 & 0.72 & 14 \\
\hline
\end{tabular}

Table 2. Holographic parameters of the sample $\mathbf{8 a}$ at $532 \mathrm{~nm}$.

\begin{tabular}{ccccccc}
\hline Polarization & $\mathrm{SDE}_{\max }, \%$ & $W_{\max }, \mathrm{kJ} /\left(\mathrm{cm}^{2} \%\right)$ & $\mathrm{REF}_{\max },(\mathrm{cm} \%)^{2} / \mathrm{kJ}$ & $\mathrm{DE}_{\mathrm{f}}, \%$ & $W_{\mathrm{f}}, \mathrm{kJ} /\left(\mathrm{cm}^{2} \%\right)$ & $\mathrm{REF}_{\mathrm{f}},(\mathrm{cm} \%)^{2} / \mathrm{kJ}$ \\
\hline $\mathrm{s}-\mathrm{s}$ & 2.50 & 3.5 & 0.71 & 1.4 & 6.0 & 0.23 \\
$\mathrm{p}-\mathrm{p}$ & 3.80 & 1.2 & 3.2 & 2.0 & 3.5 & 0.57 \\
$\mathrm{~s}-\mathrm{p}$ & 5.30 & 1.6 & 3.3 & 0.58 & 15 & 0.039 \\
$\mathrm{CE}-1$ & 32 & 0.28 & 114 & 12 & 0.76 & 16 \\
$\mathrm{CE}-2$ & 4.5 & 9.1 & 0.49 & 7.5 & 1.2 & 6.3 \\
\hline
\end{tabular}

Table 3. Holographic parameters of the sample 11 at $633 \mathrm{~nm}$.

\begin{tabular}{ccccccc}
\hline Polarization & $\mathrm{SDE}_{\max }, \%$ & $W_{\max }, \mathrm{kJ} /\left(\mathrm{cm}^{2} \%\right)$ & $\mathrm{REF}_{\max },(\mathrm{cm} \%)^{2} / \mathrm{kJ}$ & $\mathrm{DE}_{\mathrm{f}}, \%$ & $W_{\mathrm{f}}, \mathrm{kJ} /\left(\mathrm{cm}^{2} \%\right)$ & $\mathrm{REF}_{\mathrm{f}},(\mathrm{cm} \%)^{2} / \mathrm{kJ}$ \\
\hline $\mathrm{s}-\mathrm{s}$ & 1.30 & 8.0 & 0.16 & 4.40 & 2.40 & 1.8 \\
$\mathrm{p}-\mathrm{p}$ & 31.0 & 0.16 & 195 & 11.6 & 0.44 & 26 \\
$\mathrm{~s}-\mathrm{p}$ & 14.0 & 0.51 & 28 & 11.9 & 0.90 & 13 \\
$\mathrm{CE}-1$ & 15.5 & 0.45 & 34 & 15.0 & 0.52 & 29 \\
$\mathrm{CE}-2$ & 3.25 & 2.9 & 1.1 & 1.80 & 4.0 & 0.45 \\
\hline
\end{tabular}

Table 4. Holographic parameters of the sample $\mathbf{1 6}$ at $532 \mathrm{~nm}$.

\begin{tabular}{ccccccc}
\hline Polarization & $\mathrm{SDE}_{\max }, \%$ & $W_{\max }, \mathrm{kJ} /\left(\mathrm{cm}^{2} \%\right)$ & $\mathrm{REF}_{\max },(\mathrm{cm} \%)^{2} / \mathrm{kJ}$ & $\mathrm{DE}_{\mathrm{f}}, \%$ & $W_{\mathrm{f}}, \mathrm{kJ} /\left(\mathrm{cm}^{2} \%\right)$ & $\mathrm{REF}_{\mathrm{f}},\left(\mathrm{cm}^{2}\right)^{2} / \mathrm{kJ}$ \\
\hline $\mathrm{s}-\mathrm{s}$ & 0.017 & 509 & 0.000033 & 0.019 & 455 & 0.000042 \\
$\mathrm{p}-\mathrm{p}$ & 0.020 & 335 & 0.000060 & 0.012 & 720 & 0.000017 \\
$\mathrm{~s}-\mathrm{p}$ & 0.043 & 117 & 0.00037 & 0.0073 & 1200 & 0.0000061 \\
$\mathrm{CE}-1$ & 4.9 & 1.2 & 4.1 & 3.6 & 2.5 & 1.4 \\
$\mathrm{CE}-2$ & 0.36 & 17 & 0021 & 0.44 & 21 & 0.021 \\
\hline
\end{tabular}

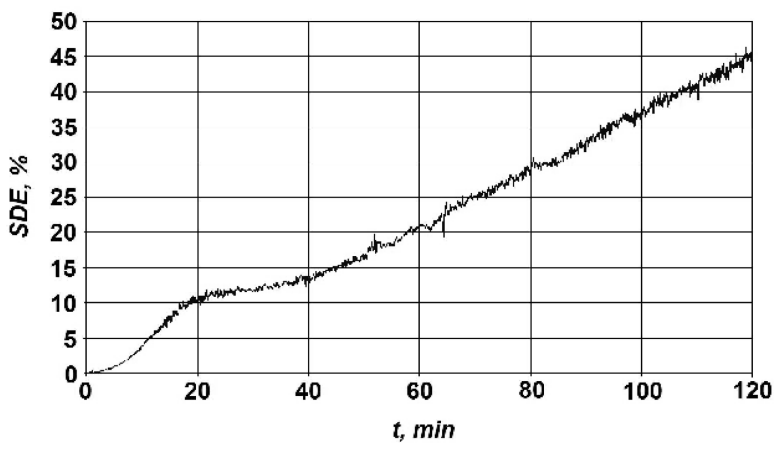

Fig. 10. SDE exposure time dependence for the sample $\mathbf{8 a}$ in the case of $\mathrm{p}-\mathrm{p}$ recording beam polarizations at $633 \mathrm{~nm}$.

were made with sample 11 at $532 \mathrm{~nm}$ and with sample 16 at $633 \mathrm{~nm}$. The reason was the very strong absorption of sample $\mathbf{1 1}$ at $532 \mathrm{~nm}$ excluding any measurements in transmission geometry. On the contrary, the transmittance of sample 16 was so high (about 0.9) that no recording at $633 \mathrm{~nm}$ was possible. One can see

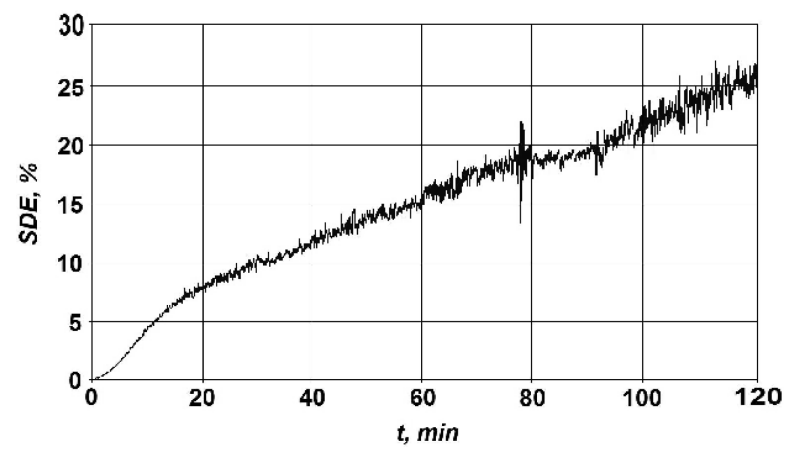

Fig. 11. SDE exposure time dependence for the sample $\mathbf{8 a}$ in the case of s-p recording beam polarizations at $633 \mathrm{~nm}$.

from the SDE exposure time dependences for samples 8a and $\mathbf{1 1}$ that in the majority of them the maximum SDE is not reached even after two hours. Only in the case of sample $\mathbf{1 6}$ the maxima were reached. However, the photosensitivity is rather low in all cases and recording energies $W_{\max }$ and $W_{\mathrm{f}}$ are high, as seen also from 


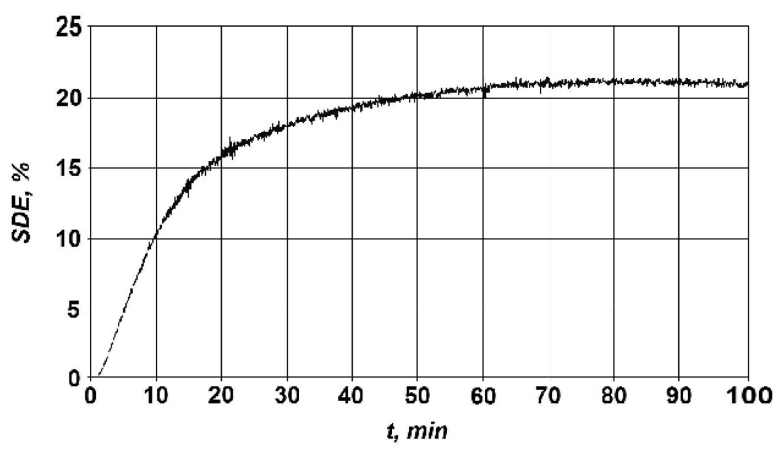

Fig. 12. SDE exposure time dependence for the sample 8a in the case of CE-1 recording beam polarizations at $633 \mathrm{~nm}$.

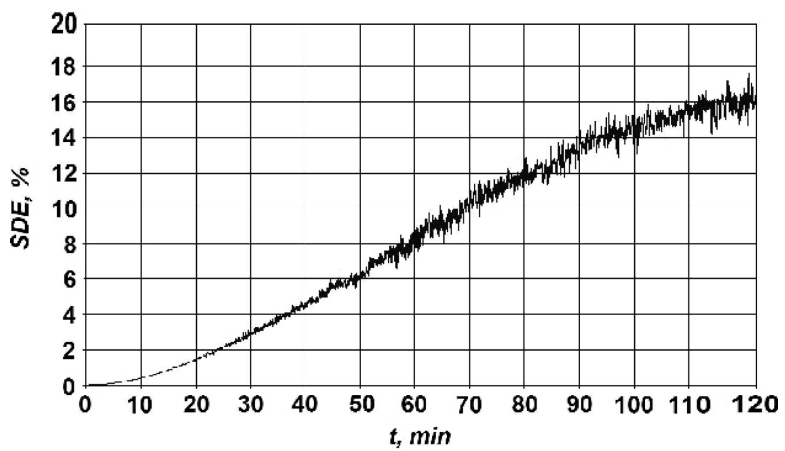

Fig. 13. SDE exposure time dependence for the sample $\mathbf{8 a}$ in the case of CE-2 recording beam polarizations at $633 \mathrm{~nm}$.

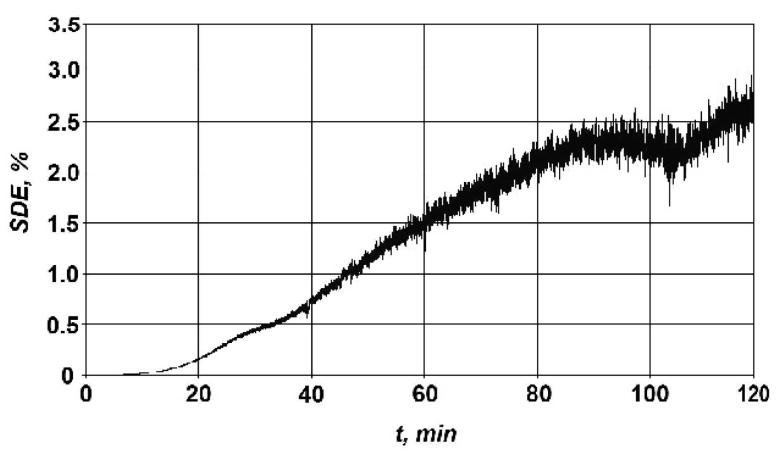

Fig. 14. SDE exposure time dependence for the sample 8a in the case of s-s recording beam polarizations at $532 \mathrm{~nm}$.

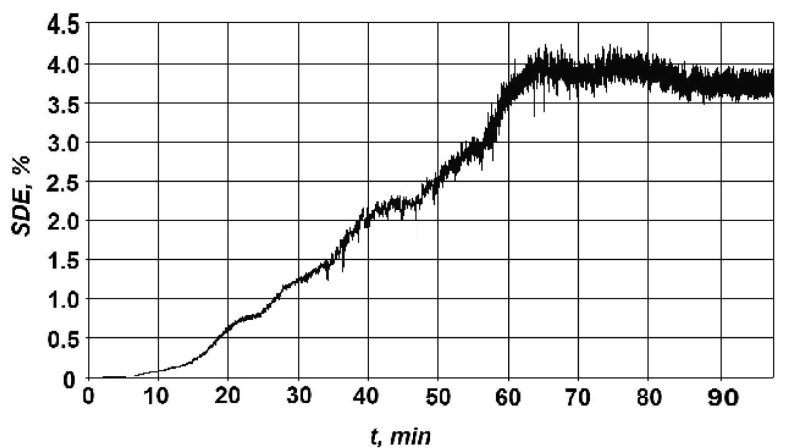

Fig. 15. SDE exposure time dependence for the sample $\mathbf{8 a}$ in the case of $\mathrm{p}-\mathrm{p}$ recording beam polarizations at $532 \mathrm{~nm}$.

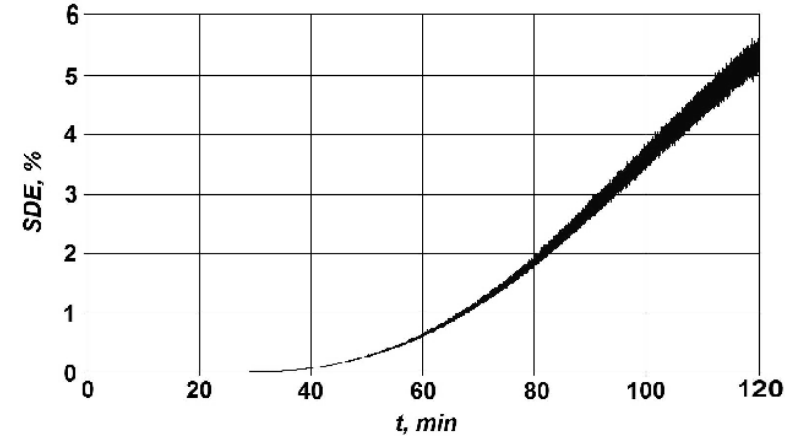

Fig. 16. SDE exposure time dependence for the sample 8a in the case of $\mathrm{s}-\mathrm{p}$ recording beam polarizations at $532 \mathrm{~nm}$.

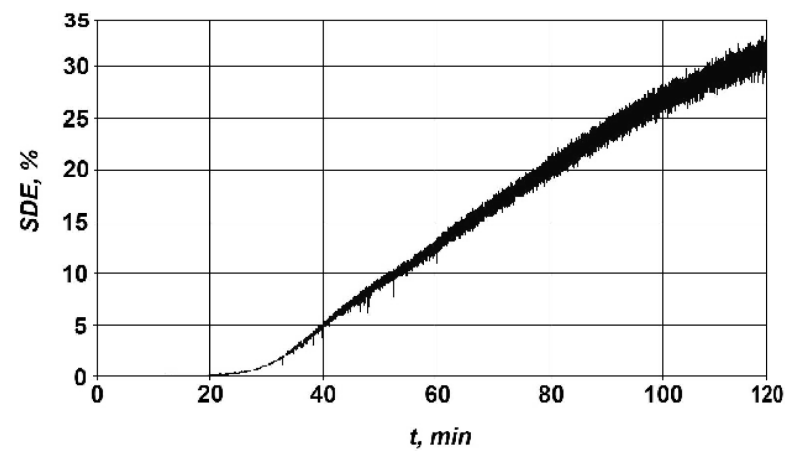

Fig. 17. SDE exposure time dependence for the sample $\mathbf{8 a}$ in the case of CE-1 recording beam polarizations at $532 \mathrm{~nm}$.

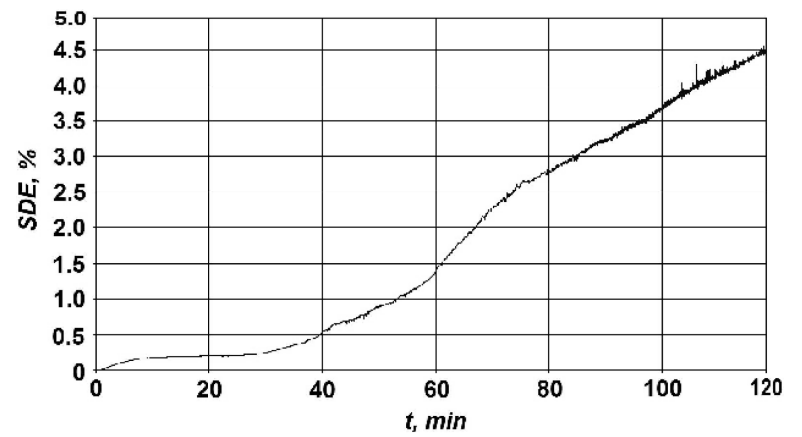

Fig. 18. SDE exposure time dependence for the sample 8a in the case of CE-2 recording beam polarizations at $532 \mathrm{~nm}$.

Tables 1-4. The oscillating behaviour of SDE curves is due to the residual set-up instabilities causing transient energy transfer between the recording beams and recording mechanism.

One can see from Tables 1-4 that efficiencies of samples 8a and $\mathbf{1 1}$ are comparable at $633 \mathrm{~nm}$ but sample 8a is the most efficient at $532 \mathrm{~nm}$. SDE up to $45 \%$ was reached in $\mathbf{8 a}$, and $\mathrm{DE}_{\mathrm{f}}$ up to $15 \%$ was reached in $\mathbf{1 1}$ at $633 \mathrm{~nm}$. At $532 \mathrm{~nm}$, the highest $\mathrm{SDE}_{\mathrm{f}}$ values of 32 and $7.5 \%$, respectively, were achieved in $\mathbf{8 a}$. The difference in SDE and DE values at 633 and $532 \mathrm{~nm}$ can be partially explained by higher absorption at $532 \mathrm{~nm}$. As a rule, $633 \mathrm{~nm}$ recording was more efficient than 
$532 \mathrm{~nm}$ one but the difference was not very large even with notably higher absorption at $532 \mathrm{~nm}$ (e. g., absorption coefficient of sample 8a was about 5 times higher at $532 \mathrm{~nm}$ than at $633 \mathrm{~nm}$ ). Sample 16 having the most complicated chemical structure (compare Fig. 3 and Figs. 1,2) was the worst. One can conclude from the obtained results that recording wavelength closer to $\lambda_{\max }$ of the sample correlates with a more efficient recording when absorption is taken into account. However, as will be seen further, this regularity is more subtle.

When efficiency of different recording beam polarizations is compared one can see from Tables 1-4 that $\mathrm{p}-\mathrm{p}$ polarizations of the recording beams are the most efficient at $633 \mathrm{~nm}$ whereas CE-1 polarizations are most efficient at $532 \mathrm{~nm}$. This means that recording mechanisms differ at 633 and $532 \mathrm{~nm}$.

As mentioned above, AFM measurements of the periodic surface relief changes photoinduced by s-s polarizations have been made. Maximum thickness changes of $25 \mathrm{~nm}$ were found in $\mathbf{8 a}$ at $532 \mathrm{~nm}$ whereas in the sample 11 they were $20 \mathrm{~nm}$ at $532 \mathrm{~nm}$ and $12 \mathrm{~nm}$ at $633 \mathrm{~nm}$. Thus higher thickness changes were created by $532 \mathrm{~nm}$ light.

Diffracted light polarization changes (anisotropic diffraction) were studied in the case of $s-p$ recording when there is no intensity modulation of the recording interference pattern but only the polarization modulation. Vector holographic gratings with SDE up to $25 \%$ and DE up to $12 \%$ were recorded in samples $8 \mathbf{a}$ and 11 at $633 \mathrm{~nm}$. The following features have been found. First, the very existence of polarization changes in the process of diffraction depends on the sample chemical composition and recording wavelength. Thus polarization changes took place in samples $\mathbf{8 a}$ and $\mathbf{1 1}$ at $633 \mathrm{~nm}$ and in sample 16 at $532 \mathrm{~nm}$ in the first diffraction orders but did not take place in the zeroth and the second diffraction orders both with two and one readout beam. No polarization changes were observed in sample $8 \mathbf{a}$ at $532 \mathrm{~nm}$. Second, the polarization changes in the same sample depended on exposure time. Thus in sample 8a at $633 \mathrm{~nm}$ the linear polarization rotation by $90^{\circ}$ was observed after 60 seconds of exposure, and the formation of elliptically polarized diffracted beams was observed after 60 minutes. The ellipticity was 6.6 in the +1 st order, and the ellipse was turned by about $8^{\circ}$ clockwise with respect to the readout linearly polarized beam. The different ellipticity of 1.2 without rotation was observed in the -1 st diffraction order. Similiar behaviour was observed also in other cases.
The marked polarization dependence of holographic recording in the studied samples and polarization changes in the process of diffraction show that azobenzene molecular glasses, generally speaking, become anisotropic and gyrotropic under the influence of polarized light. On the nanometre level, such photoinduced processes can be considered as a reorientation of molecular electric dipole transition moments perpendicularly to the light electric field vector and as a creation of anisotropic coherent photoinduced dipoles [11]. Clearly, these processes are far from being understood.

The possibility of coherent self-enhancement of holographic gratings was studied in all cases. However, usually only optical erasure of holographic gratings with one of the recording beams took place. The only exception was sample 8a exhibiting coherent selfenhancement with $\mathrm{s}-\mathrm{p}$ polarizations at $633 \mathrm{~nm}$ when read out by the s-beam, and with s-p (when read out by p-beam), CE-1, and CE-2 polarizations at $532 \mathrm{~nm}$. In the case of circular-elliptic polarizations the readout was made by the circularly polarized beam. It should be also noted that in these cases (except CE-2) the diffracted light beams expanded forming concentric ellipses. Evidently, this beam expansion is due to photoinduced lenses caused by Gaussian beams in photosensitive media. As far as we know, the effect of light polarization on coherent self-enhancement is studied for the first time.

In our opinion, the obtained results provide the evidence that trans-cis photoisomerization is the main recording mechanism at both 532 and $633 \mathrm{~nm}$. Indeed, photoinduced mass transfer takes place, and it increases when the recording wavelength approaches the trans form absorption maxima at 507 or $510 \mathrm{~nm}$. Efficiency of p-polarization is the fingerprint of light electric field gradient mechanism for photoinduced mass transfer when the viscosity of the film is decreased by trans-cis photoisomerization [4]. The density of the light electric field $(\boldsymbol{E})$ gradient force [4] in the case when $\boldsymbol{E}$ magnitude (neglecting the Gaussian beam shape) is varying only along the $x$ axis perpendicular to interference fringes is

$$
\boldsymbol{f}=\left\langle\varepsilon_{0} \chi E_{x} \frac{\partial \boldsymbol{E}}{\partial x}\right\rangle
$$

(where $\varepsilon_{0}$ is the vacuum permittivity, $\chi$ is the optically induced linear susceptibility change, brackets denote the time average). It is null when $E_{x}=0$, i.e., for the s-s polarized beam recording, and it is maximal for $\mathrm{p}$-p-polarized recording in our experiments. Thus more efficient recording by $\mathrm{p}-\mathrm{p}$ beams is the ev- 
idence of trans-cis transformations. However, calculations and additional holographic grating relaxation measurements have shown that volume gratings not surface relief gratings give the main contribution to $\mathrm{DE}$ and SDE. Difference in efficiency of CE-1 and CE-2 polarizations testifies in the favour of reorientation of molecular dipoles. The fact that recording wavelength should be close enough to the maximum of trans form also is an indication of trans-cis mechanism.

Other holographic recording mechanisms such as chromophore photodegradation [6,7] and photoorientation accompanied by coordinated alignment of adjacent backbone segments and recharging of acceptor states also contribute. This follows from the fact that the most efficient recording beam polarizations are different at 532 and $633 \mathrm{~nm}$ and that surface modulation is possible also by s-light. Even so, further studies are necessary firmly to establish the fact of red trans-cis photoisomerization.

The high enough SDE and DE of studied samples allowing stable recording of polarization holograms enable the production of polarization holographic optical elements. They can be applied also for permanent optical information recording with polarization multiplexing. Nevertheless, in these cases further optimization of these materials is necessary.

\section{Conclusions}

The recording light polarization dependence as well as polarization changes in the diffraction process are experimentally studied in three samples of azobenzene molecular glassy films of different chemical compositions 8a, 11, and 16 at 633 and $532 \mathrm{~nm}$. From the point of view of recording efficiency, chemically simpler samples 8a and $\mathbf{1 1}$ were the best at 633 and sample 8a was the best at $532 \mathrm{~nm}$. SDE up to $45 \%$ was achieved in sample 8a at $633 \mathrm{~nm}$ with $\mathrm{p}-\mathrm{p}$ polarizations. Linear $\mathrm{p}-\mathrm{p}$ polarizations were the most efficient at $633 \mathrm{~nm}$ whereas circular-elliptic polarizations CE-1 were the most efficient at $532 \mathrm{~nm}$.

Polarization holographic gratings have been recorded by s-p polarizations in samples $\mathbf{8 a}$ and $\mathbf{1 1}$ at $633 \mathrm{~nm}$, and in samples $\mathbf{8 a}$ and $\mathbf{1 6}$ at $532 \mathrm{~nm}$. Vector holograms with SDE up to $25 \%$ were recorded in $\mathbf{8 a}$ at $633 \mathrm{~nm}$ rotating the polarization of diffracted beams by $90^{\circ}$. No rotation took place at $532 \mathrm{~nm}$ in the same sample. Generally speaking, it was found that light polarization changes depended on sample chemical composition, wavelength, and exposure time.
Holographic recording was more efficient at $633 \mathrm{~nm}$ yet the photoinduced thickness modulation was larger at $532 \mathrm{~nm}$.

Mainly erasure took place when reading the holograms with one recording beam. Coherent self-enhancement was observed only in sample 8a in the case of s-p, CE-1, and CE-2 polarizations at $532 \mathrm{~nm}$, and in the case of s-p polarizations at $633 \mathrm{~nm}$.

Polarization and spectral dependences of holographic recording in the studied samples as well as AFM results have provided the evidence for the trans-cis photoisomerization based recording mechanism at both 532 and $633 \mathrm{~nm}$. Other recording mechanisms such as chromophore photodegradation and photoorientation of chromophores accompanied by coordinated alignment of adjacent backbone segments and recharging of acceptor states can also contribute.

Studied azobenzene molecular glassy films can be used for production of polarization holographic optical elements and for permanent optical information recording with polarization multiplexing.

\section{References}

[1] L. Nikolova and P.S. Ramanujam, Polarization Holography (Cambridge University Press, Cambridge, New York, etc., 2009).

[2] K. Schwartz, The Physics of Optical Recording (Springer Verlag, Berlin, 1993).

[3] S. Miyata and H. Sasabe, Light Wave Manipulation Using Organic Nonlinear Optical Materials (Taylor \& Francis, London, 2002).

[4] Z. Sekkat and W. Knoll, Photoreactive Organic Thin Films (Elsevier Science, USA, 2002).

[5] P.H. Rasmussen, P.S. Ramanujam, S. Hvilsted, and R.H. Berg, A remarkably efficient azobenzene peptide for holographic information storage, J. Am. Chem. Soc. 121, 4738-4743 (1999).

[6] Ch. Kempe, M. Rulloh, and J. Stumpe, Photoorientation of azobenzene side chain polymers parallel or perpendicular to the polarization of red HeNe light, J. Phys. Condens. Matter 15, S813-S823 (2003).

[7] A. Ozols, D. Saharov, V. Kokars, V. Kampars, A. Maleckis, G. Mezinskis, and A. Pludons, in: 16th International Conference on Defects in Insulating Materials, 24-29 August 2008, Aracaju, SE, Brazil, Book of Abstracts, AO21.

[8] D. Saharov, A. Ozols, V. Kokars, V. Kampars, G. Mezinskis, A. Maleckis, A. Pludons, and M. Rutkis, The trans-cis photoisomerization possibility of stilbene azocompounds by red light of He-Ne laser, Sci. Proc. Riga Technical University, Ser. Mater. Sci. Appl. Chem. 18, 26-34 (2008) 
[9] A. Ozols, V. Kokars, P. Augustovs, K. Traskovskis, A. Maleckis, G. Mezinskis, A. Pludons, and D. Saharov, Green and red laser holographic recording in different glassy azocompounds, Opt. Mater. (2009) [accepted].

[10] A. Ozols, D. Saharov, V. Kokars, V. Kampars, A. Maleckis, G. Mezinskis, and A. Pludons, Holo- graphic recording of surface relief gratings in stilbene azobenzene derivatives at $633 \mathrm{~nm}$, J. Phys. Conf. Ser. (2009) [accepted].

[11] D.I. Blokhintsev, Foundations of Quantum Mechanics, 5th ed. (Nauka, Moscow, 1976) [Osnovy kvantovoi mekhaniki, in Russian].

\title{
HOLOGRAFINIO ĮRAŠYMO STIKLIŠKUOSE AZOJUNGINIUOSE POLIARIZACINĖ PRIKLAUSOMYBE்
}

\author{
A. Ozols, V. Kokars, P. Augustovs, I. Uiska, K. Traskovskis, G. Mezinskis, A. Pludons, D. Saharov
}

Latvijos technikos universitetas, Ryga, Latvija

\section{Santrauka}

Eksperimentiškai tirta holografinių gardeliu įrašymo priklausomybė nuo poliarizacijos stikliškose molekulinèse azobenzenų plèvelèse 8a, 11 ir 16, naudojant 633 ir 532 nm šviesos pluoštus, kurių poliarizacijos buvo s-s, p-p ir apskritiminè-elipsinè CE-1 bei CE-2 (skiriasi šviesos elektrinio lauko sukimosi kryptimi). Paprasčiausios cheminès sandaros bandiniai $\mathbf{8 a}$ ir $\mathbf{1 1}$ buvo labiausiai efektyvūs esant $633 \mathrm{~nm}$ spinduliuotei, o bandinys $\mathbf{1 6}-532 \mathrm{~nm}$ spinduliuotei. Naudojant $p-p$ poliarizuotus įrašančiuosius $633 \mathrm{~nm}$ pluoštus, bandinyje 8 a pasiektas $45 \%$ savidifrakcijos efektyvumas (SDE). Tiesinès $\mathrm{p}-\mathrm{p}$ poliarizacijos buvo efektyviausios esant $633 \mathrm{~nm}$, o CE-1 poliarizacijos labiausiai tiko esant $532 \mathrm{~nm}$. Pastebèta, kad šviesos poliarizacijos pokyčiai vykstant difrakcijai priklauso nuo cheminès sudèties, bangos ilgio ir ekspozicijos trukmès. Vektorinès gardelès, kurių SDE siekè 25\%, irašytos bandinyje 8a tiesinę poliarizaciją pasukus $90^{\circ}$. Naudojant vieną pluoštą, daugiausia vyko gardelių ištrynimas. Koherentinis gardeliu savistiprinimas pastebètas bandinyje 8a: esant s-p bei abiem CE poliarizacijoms, kai bangos ilgis buvo $532 \mathrm{~nm}$, ir s-p poliarizaciju atveju, kai bangos ilgis buvo $633 \mathrm{~nm}$. Taip pat atlikti atominès jègos mikroskopiniai matavimai. Aptikta trans-cis fotoizomerizacijos holografinio įrašymo mechanizmo požymių esant ir 532, ir $633 \mathrm{~nm}$ spinduliuotei. Tirtas plèveles galima taikyti poliarizacijos holografinių optinių elementu gamybai ir ilgalaikiam optiniam informacijos ịrašymui. 